ROCZNIKI TEOLOGICZNE

Tom LXVIII, zeszyt $10-2021$

DOI: https://doi.org/10.18290/rt.216810.7

ANNA LADA

\title{
OPINIE MŁODZIEŻY NA TEMAT POMOCY SPOŁECZNEJ DLA OSÓB Z ZABURZENIAMI PSYCHICZNYMI
}

\author{
OPINIONS OF YOUNG PEOPLE ON SOCIAL ASSISTANCE \\ FOR PEOPLE WITH MENTAL DISORDERS
}

\begin{abstract}
A b s t r a c t. The issue of mental disorders has become a permanent part of social life. The increasingly better diagnostics and possibilities of supporting people with mental disorders highlights this phenomenon in modern society. Knowledge of others about the functioning and help of people with mental disorders affects their quality of life and the possibility of social inclusion. Research conducted on a group of over 1000 secondary school students and students from nine provinces in Poland revealed gaps and gaps in both the knowledge of mental disorders and the way in which such people function in the environment. That is why it is so important to educate generations in this area so that every person can fully enjoy their social rights and fulfill themselves to the best of their abilities.
\end{abstract}

Keywords: mental disorders; family; social assistance; youth; social exclusion.

\section{WPROWADZENIE}

Pomoc społeczna utożsamiana jest $\mathrm{z}$ pomocą finansową świadczoną na rzecz osób bezrobotnych, ubogich, opuszczonych czy seniorów. Jednak zarówno przekrój klientów pomocy społecznej jak i rodzajów wspomnianej

Dr ANNA LADA - doktor nauk społecznych, Katedra Pedagogiki Społecznej, Wydział Pedagogiki i Psychologii, Uniwersytet Marii Curie-Skłodowskiej w Lublinie; adres do korespondencji: ul. Narutowicza 12, 20-004 Lublin; e-mail: anna.lada@mail.umcs.pl; ORCID: https: //orcid.org/0000-0002-4625-0406. 
pomocy jest znacznie szerszy. Pomoc społeczna, zgodnie z zapisem ustawowym, jest ,instytucją polityki społecznej państwa, mającą na celu umożliwienie osobom i rodzinom przezwyciężanie trudnych sytuacji życiowych, których nie są one w stanie pokonać, wykorzystując własne uprawnienia, zasoby i możliwości. Pomoc społeczną organizują organy administracji rządowej i samorządowej, współpracując w tym zakresie, na zasadzie partnerstwa, z organizacjami społecznymi i pozarządowymi, Kościołem katolickim, innymi kościołami, związkami wyznaniowymi oraz osobami fizycznymi i prawnymi. Pomoc społeczna wspiera osoby i rodziny w wysiłkach zmierzających do zaspokojenia niezbędnych potrzeb i umożliwia im życie w warunkach odpowiadających godności człowieka" ${ }^{1}$. Zadaniem pomocy społecznej jest organizowanie takich działań i aktywności, które spowodują, iż jednostka lub rodzina będą w stanie przezwyciężyć trudności uniemożliwiające im normalne funkcjonowanie społeczne. Świadczenia społeczne mogą mieć wymiar finansowy i niepieniężny. Świadczenia finansowe, kierowane do osób z zaburzeniami psychicznymi, to między innymi renty czy wszelkiego rodzaju zasiłki lub zapomogi. Wsparcie niepieniężne może obejmować świadczenia rzeczowe czy świadczenia w formie usług społecznych ${ }^{2}$. Podejmowane kroki powinny uwzględniać potrzeby i możliwości rodziny czy jednostki, tak by czuła się ona podmiotem a nie przedmiotem tych działań. Każdy człowiek zasługuje na szacunek. Jak słusznie zauważa Piotr Sztompka „szacunek wyraża się nie tylko w bezpośredniej relacji z osobą szanowaną, ale także w sposobie, w jaki o niej mówimy z innymi, opiniach, plotkach, recenzjach, świadectwie, jakiego publicznie udzielamy na jej temat"3.

Osoby z zaburzeniami psychicznymi często taktowane są jako osoby niepełnosprawne intelektualnie. Pomoc, jaką powinny być objęte, często utożsamiana jest $\mathrm{z}$ pomocą kierowaną do osób $\mathrm{z}$ upośledzeniem umysłowym. W konsekwencji niewłaściwego rozumienia sposobu ich funkcjonowania, zarówno same osoby obciążone zaburzeniami psychicznymi jak i ich rodziny narażone są na stygmatyzację, nietrafny kierunek pomocy lub jej brak, a w końcu wykluczenie z życia społecznego. Należy jednak jasno zaznaczyć

${ }^{1}$ Ustawa z 12.04.2000 o pomocy społecznej, Dział I, rozdział 1, akapit 2 i 3, dostęp 10.04.2021, http://isap.sejm.gov.pl/isap.nsf/DocDetails.xsp?id=wdu20040640593.

${ }^{2}$ Renata Gierszewska, Jan Łopato, ,Zamożność, dochody, ubóstwo, świadczenia społeczne”, w Polityka społeczna, red. Grażyna Firlit-Fesnak, Małgorzata Szylko-Skoczny (Warszawa: Wydawnictwo PWN, 2013), 244.

3 Piotr Sztompka, „Szacunek”, w Fundamenty dobrego społeczeństwa. Wartości, red. Małgorzata Bogunia-Borkowska (Kraków: Wydawnictwo Znak, 2015), 255. 
iż „niepełnosprawność intelektualna (dawniej: upośledzenie umysłowe) nie jest chorobą psychiczną - i w ogóle nie jest chorobą. To jest dysfunkcja intelektualna powstająca wskutek uszkodzenia $\mathrm{z}$ różnych przyczyn układu nerwowego w okresie rozwojowym. Natomiast zapadalność tych osób na choroby psychiczne jest wyższa 3,4-krotnie niż u osób sprawnych intelektualnie. Z kolei choroba psychiczna nie jest niepełnosprawnością intelektualną, choć w przebiegu niektórych chorób psychicznych może nastąpić pogorszenie funkcjonowania intelektualnego" ${ }^{4}$.

Zaburzenia psychiczne zostały określone i skategoryzowane. Klasyfikacja ICD-10 wskazuje 9 kategorii opisujących zaburzenia psychiczne:

1. „Organiczne zaburzenia psychiczne z zespołami objawowymi,

2. Zaburzenia psychiczne i zaburzenia zachowania spowodowane używaniem substancji psychoaktywnych,

3. Schizofrenia, zaburzenia typu schizofrenii (schizotypowe) i urojeniowe,

4. Zaburzenia nerwicowe, związane ze stresem i pod postacią somatyczną (somatoform disorders),

5. Zespoły behawioralne związane z zaburzeniami fizjologicznymi i czynnikami fizycznymi,

6. Zaburzenia osobowości i zachowania dorosłych,

7. Upośledzenia umysłowe,

8. Zaburzenia rozwoju psychicznego.

9. Zaburzenia zachowania i emocji rozpoczynające się zwykle w dzieciństwie i w wieku młodzieńczym",

Pomoc społeczna kierowana do osób z zaburzeniami psychicznymi ma charakter działań wielopoziomowych. Dotyczy zarówno szeroko pojętej pomocy udzielanej osobie chorej, jej rodzinie. Dotyczy współpracy między specjalistami, opracowywania wspólnych procedur i programów działania. Zakłada włączanie w życie społeczne każdego, na miarę jego możliwości. Finalnie jest też pomocą finansową i pracą socjalną z osobami z zaburzeniami psychicznymi. Katalog metod, technik i narzędzi do pracy z takimi osobami jest bardzo szeroki. Niebagatelną rolę w tym działaniu odgrywa rodzina, która niejako jest łącznikiem między instytucjami pomocowymi a osobą potrzebująca wsparcia. Dlatego tak ważne jest, by rodziny mające w swoim otoczeniu

\footnotetext{
${ }^{4}$ Dorota Podgórska-Jachnik i Tadeusz Pietras, Praca socjalna z osobami z zaburzeniami psychicznymi i ich rodzinami (Warszawa: Centrum Rozwoju Zasobów Ludzkich, 2014), 47.

${ }^{5}$ Międzynarodowa Statystyczna Klasyfikacja Chorób i Problemów Zdrowotnych ICD-10, dostęp 10.04.2021,https://cez.gov.pl/fileadmin/user_upload/Wytyczne/statystyka/icd10tomi_56a 8f5a554a18.pdf.
} 
osoby z zaburzeniami psychicznymi, były świadome tego, na jaką pomoc ich bliscy mogą liczyć. Wiele w tej kwestii zależy od podejścia rodziny do osoby chorej i samej choroby. W przypadku akceptacji choroby, ale braku akceptacji osoby dominuje u rodziny poczucie obowiązku. Relacje są bezosobowe, pomoc i wsparcie mają charakter działań mechanicznych, występuje chłód emocjonalny, często dochodzi do oddania chorego do instytucji pomocowych, by miał tam jak najlepszą opiekę. Kiedy wśród członków rodziny brakuje akceptacji zarówno choroby jak i osoby, dominującym uczuciem jest niechęć. Możemy mówić wtedy o odrzuceniu emocjonalnym, chęci pozbycia się z otoczenia osoby chorej oraz braku potrzeby kontaktu z nim. Gdy rodzina chorego akceptuje go, ale nie akceptuje jego choroby, często można być świadkiem postawy współczującej i litości. Rodzina względem chorego jest nadopiekuńcza, wyręczająca, udziela mu nieracjonalnego wsparcia. W wielu przypadkach możemy jednak zaobserwować w rodzinach z osobą z zaburzeniami psychicznymi postawę akceptacji zarówno choroby jak i samego chorego. Dominuje wtedy miłość i sympatia. Rodzina udziela racjonalnego wsparcia, pozwala na samodzielność w miarę możliwości chorego, szacunek dla indywidualności ${ }^{6}$.

Opinie młodych ludzi na temat różnych zjawisk społecznych są znaczące, ponieważ oni będą w niedalekiej przyszłości kształtować obraz życia społecznego, oni będą kreować nowe społeczeństwo i to od nich zależeć też będzie czy każdy znajdzie dla siebie przysługujące mu miejsce w tym społeczeństwie. „Dobrą wspólnotę można budować, zaczynając od skali mikro. Od przestrzeni, na którą ma się największy wpływ. Od miejsc, które są człowiekowi najbliższe i najlepiej znane"7. Młodzi ludzie, którzy będą świadomi możliwości i ograniczeń wypływających z faktu wystąpienia różnych schorzeń o podłożu psychicznym, będą w stanie zarówno zaakceptować te osoby jak i pomóc im w inkluzji społecznej. Jak wyraził to Papież Franciszek, wielu młodych ludzi czuje w sobie potrzebę niesienia pomocy słabszym, cierpiącym. „To jest siła młodych - stwierdził Papież - siła wszystkich was, która może zmienić świat; to jest rewolucja, która może zwyciężyć moce tej ziemi: rewolucja służby" - mówił Franciszek ${ }^{8}$.

\footnotetext{
${ }^{6}$ Podgórska-Jachnik i Pietras, Praca socjalna z osobami z zaburzeniami psychicznymi i ich rodzinami, 100 .

${ }^{7}$ Małgorzata Bogunia-Borkowska, ,Życie w dobrym społeczeństwie. Wartości jako fundament dobrego społeczeństwa”, w Fundamenty dobrego społeczeństwa. Wartości, 18.

${ }^{8}$ Papież do młodych: życie ma sens tylko w służbie Bogu i bliźnim, dostęp 07.07.2021, https://www.vaticannews.va/pl/papiez/news/2018-11/papiez-franciszek-wideoprzeslanie-mlodzipanama-2019.html
} 
Zrozumienie istoty zaburzeń psychicznych, ich różnorodności nie tylko pomoże lepiej wspierać osoby dotknięte takimi zaburzeniami czy ich rodziny, ale też ryzyko wykluczenia społecznego tych jednostek zostanie zminimalizowane. Dlatego tak ważne jest, by młodzież była wyposażona w rzetelną wiedzę na ten temat, by postawy i opinie wobec osób z zaburzeniami psychicznymi miały umocowanie w obiektywnej nauce, a nie w opinii środowiska czy stereotypach funkcjonujących w społeczeństwie. Papież Franciszek, podczas spotkania ze środowiskiem nauki w 2021 roku powiedział: „Wiedza naukowa powinna być w zglobalizowanym świecie budulcem nowej kultury zdolnej do tworzenia społeczeństwa promującego godność i rozwój każdego człowieka"9.

\section{CHARAKTERYSTYKA GRUPY BADAWCZEJ}

W badaniu udział wzięła młodzież uczęszczająca do szkół średnich, zarówno liceów jak i techników oraz studenci, kształcący się w różnego typu szkołach wyższych, na różnych kierunkach studiów. Dobór próby celowo-losowy obejmował młodzież z 9 województw: dolnośląskiego, lubelskiego, małopolskiego, mazowieckiego, opolskiego, podkarpackiego, podlaskiego, śląskiego i świętokrzyskiego. Badania prowadzone były na terenie następujących 13 miast: Białystok, Częstochowa, Katowice, Komornica koło Warszawy, Kraków, Lublin, Nowy Dwór Mazowiecki, Opole, Ostrowiec Świętokrzyski, Rzeszów, Sosnowiec, Warszawa oraz Wrocław.

Grupa respondentów liczyła 1084 osoby: kobiety stanowiły większość (781 osób, to jest $72 \%$ ), niespełna co trzeci badany to mężczyzna (303 osoby, to jest $28 \%$ ). Badana młodzież w głównej mierze pochodziła z wsi - 422 osoby, (38,9\%), 1/3 respondentów zamieszkiwała duże miasto - 337 osób $(31,1 \%)$. Niespełna co piaty badany pochodził ze średniego miasta - 181 osób $(16,7 \%) .13,3 \%$ młodych ludzi zamieszkiwała w małych miastach - 144 osoby. Nieznacznie ponad połowa ankietowanych to uczniowie szkół średnich (54,2\%), 45,8\% (496 osób) to studenci. Analizując miejsce nauki, największą grupę stanowiły osoby kształcące się na uniwersytetach $(40,7 \%)$. Co dwudziesta osoba, biorąca udział w badaniu $(5,1 \%)$, uczęszczała do wyższej szkoły zawodowej, politechniki, akademii lub innej szkoły wyższej. Wśród mło-

\footnotetext{
${ }^{9}$ Papież: nauka sposobem na budowanie pokoju, dostęp 07.07.2021, https://www.vaticann ews.va/pl/papiez/news/2021-07/papiez-nauka-sposobem-na-budowanie-pokoju.html
} 
dzieży szkolnej niemal co czwarty uczeń $(38,9 \%)$ reprezentował liceum ogólnokształcące. $15,3 \%$ respondentów to uczniowie technikum.

Prowadzone badania obejmowały wiele obszarów współczesnych zagrożeń w życiu społecznym. Główny problem badawczy dotyczył przekonań badanych (młodzieży szkolnej i akademickiej) na temat zagrożeń w życiu społecznym w Polsce. Jeden z problemów szczegółowych dotyczył osób z zaburzeniami psychicznymi i brzmiał: Jaki jest stosunek badanej młodzieży? W tym obszarze znalazły się pytania i zagadnienia związane z pomocą społeczną świadczoną na rzecz osób z zaburzeniami psychicznymi.

Celem prowadzonych badań było poznanie opinii młodzieży szkolnej i studentów na temat pomocy społecznej świadczonej na rzecz osób z zaburzeniami psychicznymi. Opinie takie mogą być pomocne w przystosowaniu programów kształcenia i budowania życia społecznego w taki sposób, by każdy, zaliczony do potencjalnych grup zagrożonych wykluczeniem (w takiej grupie bez wątpienia są osoby obciążone zaburzeniami psychicznymi), nie był narażony na stygmatyzację, a mógł zajmować godne miejsce w społeczeństwie.

Badanie sondażowe przeprowadzone zostało techniką ankiety z wykorzystaniem autorskiego kwestionariusza, składającego się z 40 stwierdzeń, podzielonych na 5 części, gdzie piata część dotyczyła właśnie osób z zaburzeniami psychicznymi.

Opracowanie materiału empirycznego przygotowane zostało w oparciu o dwie techniki statystyczne: test istotności różnic t-Studenta dla grup niezależnych (poszukiwanie różnic i podobieństw na temat zjawiska wykluczenia społecznego osób z zaburzeniami psychicznymi w opiniach młodzieży uczęszczającej do szkół średnich i studentów) oraz test statystyczny $\mathrm{Chi}^{2}$ Pearsona (badanie istotnych statystycznie zależności między przekonaniami na temat zagrożenia wykluczeniem społecznym a czynnikami demograficzno-społecznymi). Obliczenia wykonano za pomocą statystycznego pakietu SPSS.

\section{OPRACOWANIE WYNIKÓW}

Pomoc społeczna, kierowania do osób z zaburzeniami psychicznymi oraz ich rodzin, to niezwykle istotny element dla prawidłowego funkcjonowania społecznego tych osób, ale też całego społeczeństwa. Dostęp do wsparcia i pomocy służb społecznych, możliwość uzyskania pełnej informacji na temat praw i możliwości leczenia jest dla osób zaburzonych psychicznie i ich rodzin elementem niezwykle ważnym i poprawiającym jakość ich życia. 
Szczegółowa analiza wyników badań pokazuje, iż młodzież, biorąca udział w badaniu, prezentuje często skrajne postawy względem stwierdzeń dotyczących osób z zaburzeniami psychicznymi.

Na podstawie uzyskanych wyników (średnich wartości) można stwierdzić, że badana młodzież jest przekonana, że warto wspierać osoby z zaburzeniami psychicznymi. Sami deklarują, iż wspierali lub wspierają finansowo osoby z zaburzeniami psychicznymi (zbiórki pieniędzy, dobroczynny sms, zbiórki darów) $(\mathrm{M}=3,15)$. Fakt ten jest oczywiście budujący i niesie pozytywny wydźwięk, wskazując na empatię i chęć niesienia pomocy słabszym. Wynikać może z tego, że w przestrzeni publicznej czy mediach społecznościowych coraz częściej pojawiają się zbiórki na różne cele, między innymi wsparcie osób z zaburzeniami psychicznymi. Często zbiórki te mają charakter inicjatyw oddolnych, indywidualnych, gdzie wspierana osoba nie jest anonimowa, dlatego też łatwiej jest się w nie włączyć.

Młodzież jest również przekonana, że zamykanie osób z zaburzeniami psychicznymi w szpitalach, na oddziałach zamkniętych, domach pomocy społecznej jest słuszne $(M=3,09)$. Taki pogląd może być uwarunkowany tym, iż młodzież nie ma wiedzy na temat możliwości funkcjonowania osób z zaburzeniami psychicznymi w środowisku. Stereotypowe opinie, brak rzetelnego kształcenia młodzieży w tym zakresie oraz brak świadomości jak wiele korzyści płynie $\mathrm{z}$ włączania ich do życia społecznego, oczywiście na miarę indywidualnych możliwości jednostki, powoduje, iż tak skrajne opinie pojawiają się wśród młodych ludzi.

Natomiast biorący udział $\mathrm{w}$ badaniu młodzi ludzie nie zgadzają się ze stanowiskiem, że w sąsiedztwie mogłaby zamieszkać osoba z zaburzeniami psychicznymi, mógłby zostać założony ośrodek wsparcia dla osób z zaburzeniami psychicznymi $(M=2,55)$. Młodzież nie zna sposobu funkcjonowania osób z zaburzeniami psychicznymi, dlatego boi się ich sąsiedztwa. Niestety osoby, które kształtują ich światopogląd (rodzice, nauczyciele, wychowawcy), rzadko podejmują dyskusję na temat stwarzania możliwie najlepszych warunków każdemu, by mógł w pełni, na miarę swoich możliwości, korzystać z życia społecznego. Moda na „normalność”, otaczanie się i pokazywanie wszystkiego w kategoriach zdrowia i dobrostanu powoduje, iż wszystko, co nie wpisuje się $w$ ten zakres, jest wypierane ze świadomości, spychane tak by nie zaburzać wzorcowego środowiska, otoczenia.

Biorący udział w badaniu nie zgadzają się też ze stwierdzeniem, że osoby z zaburzeniami psychicznymi, przebywające w placówkach medycznych (lub pomocy społecznej), mają zapewnioną wystarczającą pomoc $(\mathrm{M}=2,86)$. Kwestionowanie jakości usług zdrowotnych i pomocowych w przestrzeni publicznej przenosi się na poglądy wyrażane przez młodych ludzi. Oni sami bardzo często 
nie mają żadnej wiedzy na ten temat, jednak czerpiąc wiedzę z zasłyszanych opinii podważają warunki opieki i wspierania osób z zaburzeniami psychicznymi.

Analiza szczegółowa wykazała również, że respondenci nie podzielają poglą$\mathrm{du}$, że bezpłatna, wielostronna i powszechnie dostępna opieka zdrowotna powinna być prawem dla osób z zaburzeniami psychicznymi $(\mathrm{M}=2,15)$ oraz nie zgadzają się z twierdzeniem, że osoby z zaburzeniami psychicznymi są trudnymi klientami pomocy społecznej $(\mathrm{M}=2,48)$. Respondenci nie są przekonani, czy osoby z zaburzeniami psychicznymi potrzebują wsparcia socjalnego (dostęp do placówek, zespołu specjalistów, usług opiekuńczych) $(\mathrm{M}=2,05)$ oraz że dla ich dobra lekarze powinni współpracować z innymi specjalistami (pracownik socjalny, pielęgniarka środowiskowa, prawnik, wolontariusz) $(\mathrm{M}=2,04)$. Ten kierunek myślenia potwierdza już wcześniej wskazaną właściwość - brak wiedzy na temat funkcjonowania osób z zaburzeniami psychicznymi. Nieobecność osób z zaburzeniami psychicznymi w przestrzeni społecznej lub fakt, iż nie są widoczni, sprawia, że młodzież nie ma wiedzy na temat ich potrzeb zarówno w kontekście wsparcia i pomocy przez system opiekuńczy, placówki świadczące pomoc społeczną czy współpracę między lekarzami i innymi specjalistami.

Zastosowanie testu t-Studenta dla prób niezależnych umożliwiło sprawdzenie, czy młodzież szkolna posiada takie same poglądy na ten temat, jak ich starsi koledzy kształcący się na uczelniach (tabela, wykres).

Tabela 1. Osoby z zaburzeniami psychicznymi w obszarze pomocy społecznej - porównanie (średnie wartości)

\begin{tabular}{|l|c|c|c|c|c|c|}
\hline \multicolumn{1}{|c|}{$\begin{array}{c}\text { Stwierdzenia na temat osób } \\
\text { z zaburzeniami psychicznymi }\end{array}$} & \multicolumn{2}{c|}{ Młodzież } & \multicolumn{2}{c|}{ Studenci } & \multicolumn{2}{c|}{ Porównanie } \\
\cline { 2 - 8 } & $\mathrm{M}$ & $\mathrm{SD}$ & $\mathrm{M}$ & $\mathrm{SD}$ & $\mathrm{t}^{\circ}$ & $\mathrm{p}$ \\
\hline $\begin{array}{l}\text { Osoby z zaburzeniami psychicznymi są trud- } \\
\text { nymi klientami pomocy społecznej }\end{array}$ & 2,57 & 1,04 & 2,38 & 1,03 & 3,080 & 0,002 \\
\hline $\begin{array}{l}\text { Osoby z zaburzeniami psychicznymi potrzebuja } \\
\text { wsparcia socjalnego (dostęp do placówek, } \\
\text { zespołu specjalistów, usług opiekuńczych) }\end{array}$ & 2,22 & 1,08 & 1,84 & 0,90 & 6,110 & 0,000 \\
\hline $\begin{array}{l}\text { Zamykanie osób z zaburzeniami psychicznymi } \\
\text { w szpitalach, na oddziałach zamkniętych, } \\
\text { domach pomocy społecznej jest słuszne }\end{array}$ & 3,06 & 1,19 & 3,13 & 1,17 & $-0,950$ & 0,344 \\
\hline $\begin{array}{l}\text { Dla dobra osób z zaburzeniami psychicznymi } \\
\text { lekarze powinni współpracować z innymi } \\
\text { specjalistami (pracownik socjalny, pielęgniarka } \\
\text { środowiskowa, prawnik, wolontariusz) }\end{array}$ & 2,21 & 1,10 & 1,84 & 1,04 & 5,640 & 0,000 \\
\hline
\end{tabular}


Osoby z zaburzeniami psychicznymi mają prawo do uzyskania pomocy w zakresie nauki umiejętności zaspokajania podstawowych potrzeb życiowych, wspierania w załatwianiu spraw urzędowych itp.

Wspierałem/-am lub wspieram finansowo osoby z zaburzeniami psychicznymi (zbiórki pieniędzy, dobroczynny sms, zbiórki darów)

W moim sąsiedztwie mogłaby zamieszkać osoba z zaburzeniami psychicznymi, mógłby zostać założony ośrodek wsparcia dla osób z zaburzeniami psychicznymi

\begin{tabular}{|l|l|l|l|l|l|}
\hline 2,09 & 1,09 & 1,84 & 0,98 & 3,870 & 0,000 \\
\hline 3,10 & 1,40 & 3,22 & 1,41 & $-1,450$ & 0,146 \\
\hline 2,49 & 1,25 & 2,63 & 1,17 & $-1,980$ & 0,047 \\
\hline
\end{tabular}

Wykres 1. Osoby z zaburzeniami psychicznymi w obszarze pomocy społecznej - porównanie (średnie wartości)

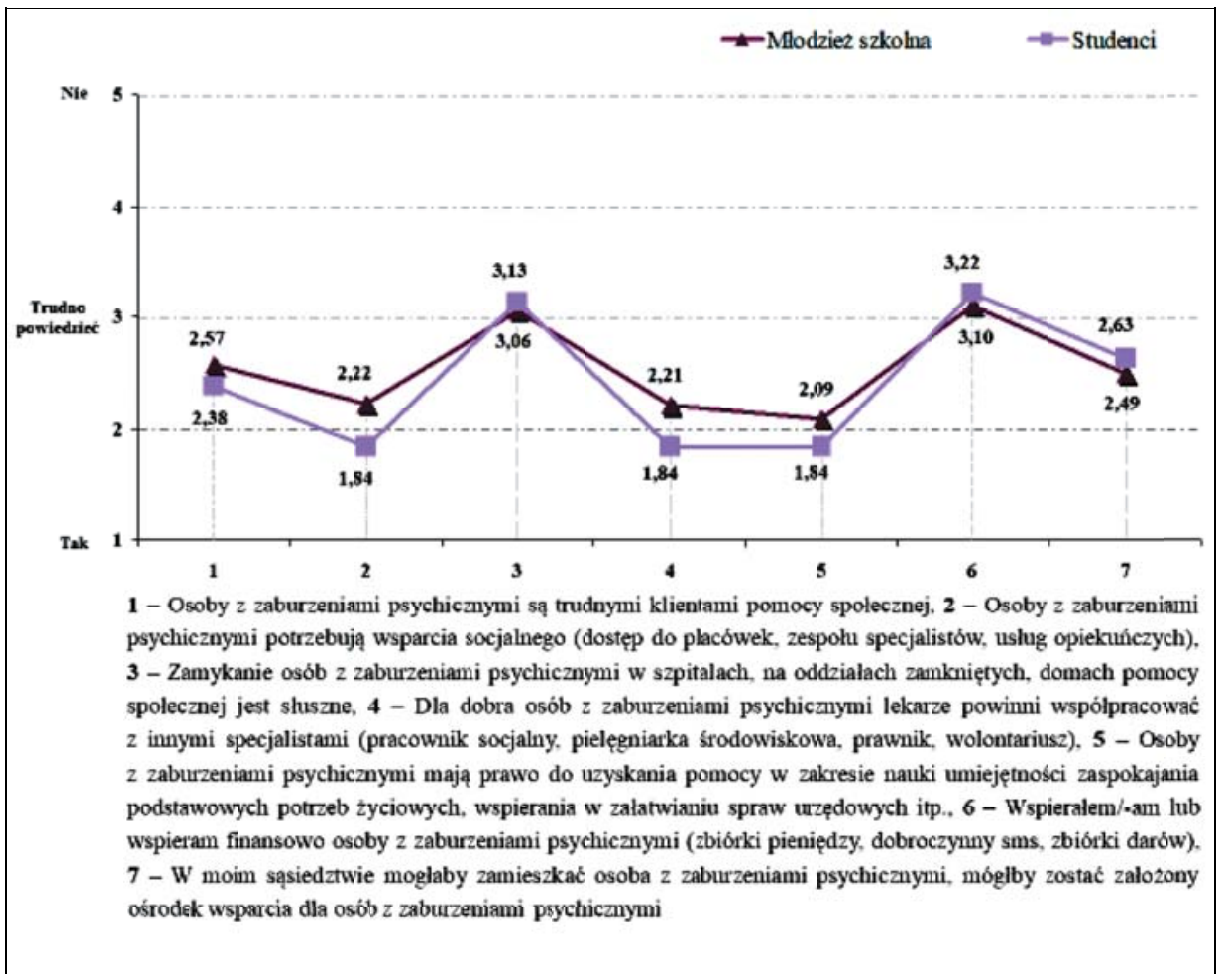


Z danych empirycznych, zawartych na powyższym wykresie wynika, że młodzież szkolna i studenci odmiennie oceniają następujące stwierdzenia na temat osób $\mathrm{z}$ zaburzeniami psychicznymi $\mathrm{w}$ obszarze pomocy społecznej: osoby z zaburzeniami psychicznymi są trudnymi klientami pomocy społecznej, osoby z zaburzeniami psychicznymi potrzebują wsparcia socjalnego (dostęp do placówek, zespołu specjalistów, usług opiekuńczych), dla dobra osób z zaburzeniami psychicznymi lekarze powinni współpracować z innymi specjalistami (pracownik socjalny, pielęgniarka środowiskowa, prawnik, wolontariusz), osoby z zaburzeniami psychicznymi maja prawo do uzyskania pomocy w zakresie nauki umiejętności zaspokajania podstawowych potrzeb oraz w moim sąsiedztwie mogłaby zamieszkać osoba z zaburzeniami psychicznymi, mógłby zostać założony ośrodek wsparcia dla osób z zaburzeniami psychicznymi.

Natomiast podobnie oceniają takie stwierdzenia, jak: zamykanie osób z zaburzeniami psychicznymi w szpitalach, na oddziałach zamkniętych, domach pomocy społecznej jest słuszne oraz wspierałem/-am lub wspieram finansowo osoby z zaburzeniami psychicznymi (zbiórki pieniędzy, dobroczynny sms, zbiórki darów).

Jak wskazują dane procentowe niemal połowa badanych studentów $(48,6 \%)$ i 39,8\% młodzieży szkół średnich jest zdania, że osoby z zaburzeniami psychicznymi maja prawo do uzyskania pomocy w zakresie nauki umiejętności zaspokajania podstawowych potrzeb życiowych, wspierania w załatwianiu spraw urzędowych itp. Co trzeci badany uczeń szkoły średniej $(31,5 \%)$ i ponad $40 \%$ studentów $(42,1 \%)$ jest zdania, że osoby z zaburzeniami psychicznymi potrzebują wsparcia socjalnego (dostęp do placówek, zespołu specjalistów, usług opiekuńczych). Niemal połowa studentów $(48,6 \%)$ i co trzeci uczeń szkoły ponadpodstawowej $(33,2 \%)$ uważa, że dla dobra osób z zaburzeniami psychicznymi lekarze powinni współpracować z innymi specjalistami (pracownik socjalny, pielęgniarka środowiskowa, prawnik, wolontariusz). Szczegółowe dane wskazują, że niemalże połowa badanych uczniów $(43,2 \%)$ i co trzeci student $(35,7 \%)$ miała trudność w jednoznacznej ocenie, że osoba z zaburzeniami psychicznymi jest raczej trudnym klientem pomocy społecznej. Podobnie, ponad 1/3 badanych (39,7\% studentów i 39,3\% uczniów) nie ma jasno sprecyzowanego poglądu, czy zamykanie osób z zaburzeniami psychicznymi w szpitalach, na oddziałach zamkniętych, domach pomocy społecznej jest słuszne. Respondenci nie wypowiedzieli się również w jednoznaczny sposób w kwestii dotyczącej mieszkania w otoczeniu osób z zaburzeniami psychicznymi. Co trzeci badany (34,4\% studentów i 32,5\% uczniowie) nie udzielił jednoznacznej przeczącej lub twierdzącej odpowiedzi, czy w jego 
Tabela 2. Osoby z zaburzeniami psychicznymi w obszarze pomocy społecznej (dane w \%)

\begin{tabular}{|c|c|c|c|c|c|c|c|c|c|c|}
\hline \multirow{2}{*}{$\begin{array}{l}\text { Stwierdzenia na temat osób } \\
\text { z zaburzeniami psychicznymi }\end{array}$} & \multicolumn{2}{|c|}{ Tak } & \multicolumn{2}{|c|}{ Raczej tak } & \multicolumn{2}{|c|}{$\begin{array}{l}\text { Trudno } \\
\text { powiedzieć }\end{array}$} & \multicolumn{2}{|c|}{ Raczej nie } & \multicolumn{2}{|c|}{ Nie } \\
\hline & $\mathrm{M}$ & $S$ & $\mathrm{M}$ & $S$ & $\mathrm{M}$ & $S$ & $\mathrm{M}$ & $S$ & M & $S$ \\
\hline $\begin{array}{l}\text { Osoby z zaburzeniami psy- } \\
\text { chicznymi sa trudnymi klienta- } \\
\text { mi pomocy społecznej }\end{array}$ & 17,3 & 23,6 & 26,5 & 29,4 & 43,2 & 35,7 & 7,3 & 8,1 & 5,6 & 3,2 \\
\hline $\begin{array}{l}\text { Osoby z zaburzeniami psy- } \\
\text { chicznymi potrzebują wsparcia } \\
\text { socjalnego (dostęp do placó- } \\
\text { wek, zespołu specjalistów, } \\
\text { usług opiekuńczych) }\end{array}$ & 31,5 & 42,1 & 29,4 & 36,9 & 29,1 & 16,7 & 6,0 & 2,8 & 4,1 & 1,4 \\
\hline $\begin{array}{l}\text { Zamykanie osób z zaburzenia- } \\
\text { mi psychicznymi w szpitalach, } \\
\text { na oddziałach zamkniętych, do- } \\
\text { mach pomocy społecznej jest } \\
\text { słuszne }\end{array}$ & 12,2 & 10,1 & 16,3 & 16,3 & 39,3 & 39,7 & 17,2 & 18,1 & 15,0 & 15,7 \\
\hline $\begin{array}{l}\text { Dla dobra osób z zaburzeniami } \\
\text { psychicznymi lekarze powinni } \\
\text { współpracować z innymi spe- } \\
\text { cjalistami (pracownik socjalny, } \\
\text { pielęgniarka środowiskowa, } \\
\text { prawnik, wolontariusz) }\end{array}$ & 33,2 & 48,6 & 27,9 & 29,6 & 28,1 & 14,9 & 6,8 & 3,0 & 4,1 & 3,8 \\
\hline $\begin{array}{l}\text { Osoby z zaburzeniami psy- } \\
\text { chicznymi maja prawo do uzy- } \\
\text { skania pomocy w zakresie } \\
\text { nauki umiejętności zaspoka- } \\
\text { jania podstawowych potrzeb } \\
\text { życiowych, wspierania w zała- } \\
\text { twianiu spraw urzędowych itp. }\end{array}$ & 39,8 & 46,8 & 24,1 & 29,4 & 26,7 & 19,1 & 6,1 & 2,0 & 3,2 & 2,6 \\
\hline $\begin{array}{l}\text { Wspierałem/-am lub wspieram } \\
\text { finansowo osoby z zaburzenia- } \\
\text { mi psychicznymi (zbiórki pie- } \\
\text { niędzy, dobroczynny sms, } \\
\text { zbiórki darów) }\end{array}$ & 18,2 & 15,5 & 15,6 & 18,1 & 28,1 & 21,2 & 14,5 & 19,0 & 23,6 & 26,2 \\
\hline $\begin{array}{l}\text { W moim sásiedztwie mogłaby } \\
\text { zamieszkać osoba z zaburze- } \\
\text { niami psychicznymi, mógłby } \\
\text { zostać założony ośrodek wspar- } \\
\text { cia dla osób z zaburzeniami } \\
\text { psychicznymi }\end{array}$ & 29,4 & 20,6 & 19,9 & 24,2 & 32,5 & 34,5 & 9,0 & 12,9 & 9,2 & 7,9 \\
\hline
\end{tabular}

sąsiedztwie mogłaby zamieszkać osoba z zaburzeniami psychicznymi, mógłby zostać założony ośrodek wsparcia dla osób z zaburzeniami psychicznymi; co czwarta badana osoba (26,2\% studentów i 23,6\% uczniów) odpowiedziała przecząco na twierdzenie dotyczące wspierania finansowego osób z zaburzeniami psychicznymi. 
Szczegółowa analiza zabranych danych wskazuje, iż płeć koreluje, na mającym znaczenie poziomie, $\mathrm{z}$ następującymi stwierdzeniami na temat osób z zaburzeniami psychicznymi $\mathrm{w}$ obszarze pomocy społecznej: osoby $\mathrm{z}$ zaburzeniami psychicznymi potrzebują wsparcia socjalnego (dostęp do placówek, zespołu specjalistów, usług opiekuńczych), zamykanie osób z zaburzeniami psychicznymi w szpitalach, na oddziałach zamkniętych, domach pomocy społecznej jest słuszne, dla dobra osób z zaburzeniami psychicznymi lekarze powinni współpracować z innymi specjalistami (pracownik socjalny, pielęgniarka środowiskowa, prawnik, wolontariusz) oraz osoby z zaburzeniami psychicznymi mają prawo do uzyskania pomocy w zakresie nauki umiejętności zaspokajania podstawowych potrzeb życiowych, wspierania w załatwianiu spraw urzędowych itp.

Kobiety częściej niż mężczyźni zgadzają się z następującymi stwierdzeniami na temat osób z zaburzeniami psychicznymi w obszarze pomocy społecznej: osoby z zaburzeniami psychicznymi potrzebują wsparcia socjalnego (dostęp do placówek, zespołu specjalistów, usług opiekuńczych) (38,4\%), dla dobra osób z zaburzeniami psychicznymi lekarze powinni współpracować z innymi specjalistami (pracownik socjalny, pielęgniarka środowiskowa, prawnik, wolontariusz) $(44,1 \%)$ oraz osoby $\mathrm{z}$ zaburzeniami psychicznymi maja prawo do uzyskania pomocy w zakresie nauki umiejętności zaspokajania podstawowych potrzeb życiowych, wspierania w załatwianiu spraw urzędowych itp. (46,2\%). Natomiast zdania nie wyrażają w przypadku następującego stwierdzenia: zamykanie osób $\mathrm{z}$ zaburzeniami psychicznymi w szpitalach, na oddziałach zamkniętych, domach pomocy społecznej jest słuszne $(39,2 \%)$.

Wiek stanowi również wskaźnik, który koreluje na istotnym poziomie z następującymi stwierdzeniami na temat osób z zaburzeniami psychicznymi w obszarze pomocy społecznej: osoby z zaburzeniami psychicznymi sa trudnymi klientami pomocy społecznej, osoby z zaburzeniami psychicznymi potrzebują wsparcia socjalnego (dostęp do placówek, zespołu specjalistów, usług opiekuńczych), dla dobra osób z zaburzeniami psychicznymi lekarze powinni współpracować z innymi specjalistami (pracownik socjalny, pielęgniarka środowiskowa, prawnik, wolontariusz) oraz osoby z zaburzeniami psychicznymi maja prawo do uzyskania pomocy w zakresie nauki umiejętności zaspokajania podstawowych potrzeb życiowych, wspierania w załatwianiu spraw urzędowych itp.

Młodzież w wieku 19-20 lat częściej niż pozostali badani zgadza się z następującymi stwierdzeniami na temat osób z zaburzeniami psychicznymi w obszarze pomocy społecznej: osoby z zaburzeniami psychicznymi potrzebują wsparcia socjalnego (dostęp do placówek, zespołu specjalistów, usług opiekuńczych) (31,6\%), dla dobra osób z zaburzeniami psychicznymi lekarze powinni współpracować z innymi specjalistami (pracownik socjalny, pielęg- 
niarka środowiskowa, prawnik, wolontariusz) $(34,3 \%)$ oraz osoby z zaburzeniami psychicznymi mają prawo do uzyskania pomocy $\mathrm{w}$ zakresie nauki umiejętności zaspokajania podstawowych potrzeb życiowych, wspierania w załatwianiu spraw urzędowych itp. $(37,8 \%)$. Natomiast zdania nie wyrażaja w przypadku następującego stwierdzenia: osoby z zaburzeniami psychicznymi są trudnymi klientami pomocy społecznej $(44,0 \%)$.

Miejsce nauki koreluje na poziomie istotnym z następującymi stwierdzeniami na temat osób z zaburzeniami psychicznymi w obszarze pomocy społecznej: osoby z zaburzeniami psychicznymi są trudnymi klientami pomocy społecznej, osoby z zaburzeniami psychicznymi potrzebują wsparcia socjalnego (dostęp do placówek, zespołu specjalistów, usług opiekuńczych), dla dobra osób z zaburzeniami psychicznymi lekarze powinni współpracować z innymi specjalistami (pracownik socjalny, pielęgniarka środowiskowa, prawnik, wolontariusz), osoby z zaburzeniami psychicznymi maja prawo do uzyskania pomocy w zakresie nauki umiejętności zaspokajania podstawowych potrzeb życiowych, wspierania w załatwianiu spraw urzędowych itp. oraz w moim sąsiedztwie mogłaby zamieszkać osoba z zaburzeniami psychicznymi, mógłby zostać założony ośrodek wsparcia dla osób z zaburzeniami psychicznymi.

Uczniowie częściej niż pozostali badani zgadzają się z następującymi stwierdzeniami na temat osób z zaburzeniami psychicznymi w obszarze pomocy społecznej: osoby z zaburzeniami psychicznymi potrzebują wsparcia socjalnego (dostęp do placówek, zespołu specjalistów, usług opiekuńczych) $(31,5 \%)$, dla dobra osób z zaburzeniami psychicznymi lekarze powinni współpracować z innymi specjalistami (pracownik socjalny, pielęgniarka środowiskowa, prawnik, wolontariusz) $(48,6 \%)$ i osoby z zaburzeniami psychicznymi mają prawo do uzyskania pomocy w zakresie nauki umiejętności zaspokajania podstawowych potrzeb życiowych, wspierania w załatwianiu spraw urzędowych itp. $(39,8 \%)$. Natomiast zdania nie wyrażają w przypadku następujących stwierdzeń: osoby z zaburzeniami psychicznymi są trudnymi klientami pomocy społecznej $(43,2 \%)$ oraz w moim sąsiedztwie mogłaby zamieszkać osoba z zaburzeniami psychicznymi, mógłby zostać założony ośrodek wsparcia dla osób z zaburzeniami psychicznymi (32,5\%).

Miejsce zamieszkania koreluje jedynie $\mathrm{z}$ jednym stwierdzeniem na temat osób z zaburzeniami psychicznymi w obszarze pomocy społecznej: wspierałem/am lub wspieram finansowo osoby z zaburzeniami psychicznymi (zbiórki pieniędzy, dobroczynny sms, zbiórki darów).

Mieszkańcy miast powyżej 100 tys. mieszkańców częściej niż pozostali badani nie wyrażają zdania w przypadku stwierdzenia, że wspierałem/am lub 
wspieram finansowo osoby z zaburzeniami psychicznymi (zbiórki pieniędzy, dobroczynny sms, zbiórki darów) (32,0\%).

$\mathrm{Z}$ kolei rodzaj uczelni/szkoły koreluje na poziomie istotnym z następującymi stwierdzeniami na temat osób $\mathrm{z}$ zaburzeniami psychicznymi w obszarze pomocy społecznej: osoby z zaburzeniami psychicznymi są trudnymi klientami pomocy społecznej, osoby z zaburzeniami psychicznymi potrzebują wsparcia socjalnego (dostęp do placówek, zespołu specjalistów, usług opiekuńczych), zamykanie osób z zaburzeniami psychicznymi w szpitalach, na oddziałach zamkniętych, domach pomocy społecznej jest słuszne, dla dobra osób z zaburzeniami psychicznymi lekarze powinni współpracować z innymi specjalistami (pracownik socjalny, pielęgniarka środowiskowa, prawnik, wolontariusz), osoby z zaburzeniami psychicznymi maja prawo do uzyskania pomocy w zakresie nauki umiejętności zaspokajania podstawowych potrzeb życiowych, wspierania w załatwianiu spraw urzędowych itp. oraz w moim sąsiedztwie mogłaby zamieszkać osoba z zaburzeniami psychicznymi, mógłby zostać założony ośrodek wsparcia dla osób z zaburzeniami psychicznymi.

Uczniowie liceów ogólnokształcących częściej niż pozostali badani zgadzają się z następującymi stwierdzeniami na temat osób z zaburzeniami psychicznymi w obszarze pomocy społecznej: osoby z zaburzeniami psychicznymi potrzebują wsparcia socjalnego (dostęp do placówek, zespołu specjalistów, usług opiekuńczych) (31,3\%), dla dobra osób z zaburzeniami psychicznymi lekarze powinni współpracować z innymi specjalistami (pracownik socjalny, pielęgniarka środowiskowa, prawnik, wolontariusz) (36,5\%), osoby z zaburzeniami psychicznymi maja prawo do uzyskania pomocy w zakresie nauki umiejętności zaspokajania podstawowych potrzeb życiowych, wspierania w załatwianiu spraw urzędowych itp. $(41,9 \%)$ Natomiast zdania nie wyrażają w przypadku następujących stwierdzeń: osoby z zaburzeniami psychicznymi są trudnymi klientami pomocy społecznej (44,3\%), zamykanie osób z zaburzeniami psychicznymi w szpitalach, na oddziałach zamkniętych, domach pomocy społecznej jest słuszne $(40,8 \%)$ oraz w moim sąsiedztwie mogłaby zamieszkać osoba z zaburzeniami psychicznymi, mógłby zostać założony ośrodek wsparcia dla osób z zaburzeniami psychicznymi $(34,1 \%)$.

Opinie młodzieży w kontekście pomocy społecznej, udzielanej osobom z zaburzeniami psychicznymi sugerują, iż młodzi ludzie kreują swój światopogląd nie mając wystarczającej wiedzy na temat funkcjonowania osób z zaburzeniami psychicznymi. Przypuszczać można, iż młodzi ludzie bazują na wiedzy, poglądach, jakie wynieśli z domów rodzinnych, z opinii, jakie mieli szansę słyszeć w środowisku, w którym przebywają. Dlatego tak ważna $\mathrm{w}$ tym aspekcie jest edukacja, zarówno ta nieformalna prowadzona w domu 
rodzinnym, jak i formalna prowadzona w placówkach oświatowych. Należy budować społeczeństwo, gdzie każdy może znaleźć dla siebie przestrzeń, gdzie każdy, mimo swoich ograniczeń czy dysfunkcji ma należne mu miejsce, gdzie jego rodzina nie jest narażona na stygmatyzację i wykluczenie. Odpowiednio dopasowana pomoc powinna być źródłem motywacji do samodzielności dla osoby, u której zdiagnozowano zaburzenia psychiczne.

\section{BIBLIOGRAFIA}

Bogunia-Borkowska, Małgorzata. „Życie w dobrym społeczeństwie. Wartości jako fundament dobrego społeczeństwa”. W Fundamenty dobrego społeczeństwa. Wartości, red. Małgorzata Bogunia-Borkowska. Kraków: Wydawnictwo Znak, 2015.

Gierszewska, Renata, Jan Łopato. „Zamożność, dochody, ubóstwo, świadczenia społeczne”. W Polityka społeczna, red. Grażyna Firlit-Fesnak, Małgorzata Szylko-Skoczny. Warszawa: Wydawnictwo PWN, 2013.

Podgórska-Jachnik, Dorota i Tadeusz Pietras. Praca socjalna z osobami z zaburzeniami psychicznymi i ich rodzinami. Warszawa: Centrum Rozwoju Zasobów Ludzkich, 2014.

Sztompka, Piotr. „Szacunek”. W Fundamenty dobrego spoteczeństwa. Wartości, red. Małgorzata Bogunia-Borkowska. Kraków: Wydawnictwo Znak, 2015.

Międzynarodowa Statystyczna Klasyfikacja Chorób i Problemów Zdrowotnych ICD-10, dostęp 10.04.2021, https://cez.gov.pl/fileadmin/user_upload/Wytyczne/statystyka/icd10tomi_56a8f 5a554a18.pdf.

Papież do młodych: życie ma sens tylko w służbie Bogu i bliźnim, dostęp 07.07.2021, https: //www.vaticannews.va/pl/papiez/news/2018-11/papiez-franciszek-wideoprzeslanie-mlodzi-pan ama-2019.html.

Papież: nauka sposobem na budowanie pokoju, dostęp 07.07.2021, https://www.vaticannews.va /pl/papiez/news/2021-07/papiez-nauka-sposobem-na-budowanie-pokoju.html.

Ustawa z 12.04.2000 o pomocy społecznej, dostęp 10.04.2021, http://isap.sejm.gov.pl/isap.nsf/D ocDetails.xsp?id=wdu20040640593.

\section{OPINIE MŁODZIEŻY NA TEMAT POMOCY SPOŁECZNEJ \\ DLA OSÓB Z ZABURZENIAMI PSYCHICZNYMI}

$$
\text { S t r e s z c z e n i e }
$$

Problematyka zaburzeń psychicznych na stałe wpisała się w życie społeczne. Coraz lepsza diagnostyka i możliwości wsparcia osób z zaburzeniami psychicznymi uwypuklają to zjawisko we współczesnym społeczeństwie. Wiedza innych na temat funkcjonowania i pomocy osobom z zaburzeniami psychicznymi wpływa na jakość ich życia, możliwości inkluzji społecznej. Badania, prowadzone na grupie ponad 1000 uczniów szkół ponadpodstawowych i studentów 
z dziewięciu województw w Polsce, wskazały luki i braki zarówno w stanie wiedzy na temat zaburzeń psychicznych jak i sposobu funkcjonowania takich osób w środowisku. Dlatego tak istotne jest kształcenie pokoleń w tym zakresie, by każdy człowiek mógł w pełni korzystać z przysługujących mu praw społecznych oraz realizować się na miarę swoich możliwości.

Słowa kluczowe: zaburzenia psychiczne; rodzina; pomoc społeczna; młodzież; wykluczenie społeczne. 